\title{
Development of Nanocomposite Adsorbents for Heavy Metal Removal from Wastewater
}

Bin Wang, ${ }^{1,2}$ Tingting Wu, ${ }^{3}$ Subramania Angaiah, ${ }^{4}$ Vignesh Murugadoss, ${ }^{4}$ Jong-Eun Ryu, ${ }^{5}$ Evan K. Wujcik, ${ }^{6}$ Na Lu, ${ }^{7}$ David P. Young, Qiang Gao and Zhanhu Guo ${ }^{1 *}$

Development of highly efficient, low cost adsorbents for heavy metal ion removal from wastewater is an enduring undertaking. Two major groups of nanocomposite adsorbents are reviewed here. The magnetic carbon family is first discussed including the preparation of such materials. Various carbon sources have been used in the preparation, and the structural characteristics have been analyzed. Cr(VI) removal studies unveil a wide range of performance. The second group adsorbents is polymer functionalized nanocomposites. One notable polymer is polyaniline which is a redox polymer. The redox nature allows the composite materials to facilitate $\mathrm{Cr}(\mathrm{VI})$ reduction to $\mathrm{Cr}$ (III) which is prone to precipitate under neutral $\mathrm{pH}$ condition. The studies show that polyaniline can be feasibly synthesized in situ to cover the support surface, while the support provides mechanical strength and suitable surface area for $\mathrm{Cr}$ adsorption. A similar approach is the in situ synthesis of poly(acrylic acid) in the presence of support materials. This group of materials have been applied in $\mathrm{Pb}$ (II) removal and the performance is analyzed.

Keywords: Heavy metal removal; Nanocomposite; Magnetic carbon; Core/shell structure; Polyaniline

Received 14 October 2018, Accepted 3 December 2018

DOI: $10.30919 / \mathrm{esmm} 5 \mathrm{f} 175$

\section{Introduction}

Large amounts of wastewater are conspicuously generated by industrial, agricultural, and domestic activities worldwide..$^{1-3}$ Three primary pollutants are found in the wastewater: microorganisms, organics, and inorganics. A major part of inorganic pollutants are heavy metal ions that have aroused lots of concern due to their toxicities to ecological and biological systems. ${ }^{48}$ According to the United States Environmental

${ }^{1}$ Integrated Composites Laboratory (ICL), Department of Chemical \& Biomolecular Engineering, University of Tennessee, Knoxville, TN 37966, USA

${ }^{2}$ Engineered Multifunctional Composites (EMC) Nanotech, Knoxville, TN 37934, USA

${ }^{3}$ Civil and Environmental Engineering Department, The University of Alabama in Huntsville, Huntsville, AL 35899, USA

${ }^{4}$ Electrochemical Energy Research Lab, Centre for Nanoscience and Technology, Pondicherry University, Puducherry - 605 014, India

${ }^{5}$ Department of Mechanical and Aerospace Engineering, North Carolina State University, Raleigh, NC 27695, USA

${ }^{6}$ Department of Chemical and Biological Engineering, The University of Alabama, Tuscaloosa, AL 35487, USA

${ }^{7}$ Lyles School of Civil Engineering, School of Materials Engineering, Birck Nanotechnology Center, Purdue University, West Lafayette, IN 47906, USA

${ }^{8}$ Department of Physics and Astronomy, Louisiana State University, Baton Rouge, LA 70803, USA

${ }^{9}$ Max Planck Institute for Chemical Energy Conversion, Stiftstrasse 3436, 45470 Mülheim an der Ruhr, Germany

*E-mail: zguo10@utk.edu
Protection Agency (EPA), the levels of various metal ions in drinking water have been limited. Table 1 lists some of these ions and the corresponding effects on human health. ' Currently, increasing contamination in wastewater systems is a critical problem urgently needing to be solved. The heavy metals such as arsenic (As), cadmium $(\mathrm{Cd})$, chromium $(\mathrm{Cr})$, lead $(\mathrm{Pb})$, and mercury $(\mathrm{Hg})$ attract particular interests due to their high toxicity and extremely low degradation rate. These polluting species result from industries including metal plating facilities, mining operations, fertilizer industries, tanneries, batteries, paper industries and pesticides. Numerous studies have shown the heavy metal pollutants can cause severe public health problems to animals and human beings since they can be stored, accumulated and transferred by organisms.

A tremendous amount of research focuses on water pollution due to heavy metal ions. Methods developed to circumvent heavy metal pollution include adsorption, ${ }^{10,11}$ ion exchange, ${ }^{12,13}$ membrane filtration, ${ }^{14,15}$ electrochemical precipitation, ${ }^{16,17}$ reverse osmosis, ${ }^{18,19}$ and flocculation. ${ }^{20,21}$ Among these methods, adsorption is most widely used to remove metal ions from wastewater. This method is simple, economical, and highly efficient. ${ }^{22,23}$ Experimented adsorbents include carbon materials, ${ }^{24,25}$ metal oxides, ${ }^{26,27}$ clays, ${ }^{28,29}$ zeolits, ${ }^{30,31}$ biomass, ${ }^{32,33}$ and polymers. ${ }^{34,35}$

Among the heavy metal ions, chromium $(\mathrm{Cr})$ is a common contaminant in surface and ground water. It is widely applied in electroplating, leather tanning, printing, and other metallurgy industries. ${ }^{36,37}$ The valence states existent in chromium range from +6 to -4 , but only trivalent and hexavalent forms are stable in most natural environment. ${ }^{38}$ Hexavalent chromium $\mathrm{Cr}(\mathrm{VI})$ is 500 times more toxic and carcinogenic than trivalent chromium $\mathrm{Cr}(\mathrm{III}) .{ }^{39} \mathrm{Cr}(\mathrm{VI})$ is considered to cause severe diseases such as dermatitis and lung cancer. ${ }^{40}$ According to the drinking water regulations recommended by EPA, the maximum concentration for total $\mathrm{Cr}$ in drinking water is $0.1 \mathrm{mg} \mathrm{L}^{-1}$. 11 The World 
Table 1 EPA maximum contaminant levels in drinking water and corresponding health effects.

\begin{tabular}{lll}
\hline \multicolumn{1}{c}{ Metal } & $\begin{array}{c}\text { MCL } \\
(\mathrm{ppb})^{\mathrm{a}}\end{array}$ & \multicolumn{1}{c}{ Health effects } \\
\hline Arsenic (As) & 10 & Skin damage or circulatory system problems, cancer risk may increase \\
Cadmium (Cd) & 5 & Kidney damage \\
Chromium $(\mathrm{Cr})$ & 100 & Allergic dermatitis \\
Copper $(\mathrm{Cu})$ & 1300 & Gastrointestinal distress, liver or kidney damage \\
Lead $(\mathrm{Pb})$ & 15 & $\begin{array}{l}\text { Deficits in attention span and learning abilities, kidney problems, blood } \\
\text { pressure increases }\end{array}$ \\
Mercury $(\mathrm{Hg})$ & 2 & Kidney damage \\
Uranium $(\mathrm{U})$ & 30 & Cancer risk increases, kidney toxicity \\
\hline
\end{tabular}

${ }^{a} \mathrm{MCL}$ : maximum contaminant level; ppb, parts per billion, $1 \mathrm{ppb}=1 \mu \mathrm{g} \mathrm{\textrm {L } ^ { - 1 }}$

Health Organization (WHO) recommends the maximum allowable limit for $\mathrm{Cr}(\mathrm{VI})$ in drinking water of $0.05 \mathrm{mg} \mathrm{L}^{-142}$ Rapid, efficient and economical technologies to stringently remove $\mathrm{Cr}(\mathrm{VI})$ from polluted water are actively pursued.

$\mathrm{Cr}(\mathrm{VI})$ in wastewater exists as chromate $\left(\mathrm{CrO}_{4}^{2-}\right)$, dichromate $\left(\mathrm{Cr}_{2} \mathrm{O}_{7}^{2-}\right)$ and hydrogen chromate $\left(\mathrm{HCrO}_{4}^{-}\right.$and $\left.\mathrm{H}_{2} \mathrm{CrO}_{4}\right)$, dependent on the $\mathrm{pH}$ value and total chromate concentration in the solution. The $\mathrm{HCrO}_{4}^{-}$is the dominant form in solutions with $\mathrm{pH}$ value lower than 6.8 , while only $\mathrm{CrO}_{4}^{2-}$ is stable when $\mathrm{pH}$ is above 6.8 . $\mathrm{HCrO}_{4}^{-}$has a higher redox potential $(1.33 \mathrm{~V})$ than $\mathrm{CrO}_{4}^{2-}$ and can be more readily reduced to Cr(III):

$$
\begin{aligned}
& \mathrm{H}_{2} \mathrm{CrO}_{4} \leftrightarrows \mathrm{H}^{+}+\mathrm{HCrO}_{4}^{-}, K=10^{-0.75} \\
& \mathrm{HCrO}_{4}{ }^{-} \leftrightarrows \mathrm{H}^{+}+\mathrm{CrO}_{4}{ }^{2-}, K=10^{-6.45} \\
& \mathrm{HCrO}_{4}^{-}+7 \mathrm{H}^{+}+3 \mathrm{e}^{-} \rightarrow \mathrm{Cr}(\mathrm{III}) \downarrow+4 \mathrm{H}_{2} \mathrm{O}, E_{0}=1.33 \mathrm{~V}
\end{aligned}
$$

A variety of technologies have been developed for environmental cleanup and remediation of $\mathrm{Cr}(\mathrm{VI})$ from waste or drinking water, such as electrochemical precipitation, ${ }^{16}$ reverse osmosis, ${ }^{14}$ ion exchange, ${ }^{12}$ photocatalytic degradation, ${ }^{43}$ chemical reduction ${ }^{44}$ and adsorption. ${ }^{45}$ Chemical reduction demonstrates specific advantages toward $\mathrm{Cr}(\mathrm{VI})$ removal from wastewater system. ${ }^{46} \mathrm{Cr}(\mathrm{VI})$ is highly toxic, very soluble and mobile in the aqueous environment. $\mathrm{Cr}$ (III) is formed after $\mathrm{Cr}(\mathrm{VI})$ reduction which is relatively immobile, because $\mathrm{Cr}(\mathrm{III})$ has a low redox potential $\left(E_{\mathrm{h}}=-0.74 \mathrm{~V}\right)$ and a low water solubility $\left(<10^{-5} \mathrm{M}\right)$ over a wide $\mathrm{pH}$ range. ${ }^{47} \mathrm{In}$ fact, $\mathrm{Cr}(\mathrm{III})$ is an essential nutrient for the proper functioning of living organisms. ${ }^{48}$ The combination of $\mathrm{Cr}(\mathrm{VI})$ reduction to $\mathrm{Cr}$ (III) and subsequent adsorption or even precipitation of $\mathrm{Cr}$ (III) has been pursued as a promising method for $\mathrm{Cr}(\mathrm{VI})$ removal. $^{49}$

This review primarily addresses the development of nanocomposite adsorbents for adsorption of $\mathrm{Cr}(\mathrm{VI})$ from aqueous solution experimented in our laboratories. The high specific surface area is the most accredited characteristic of these nanocomposite adsorbents for the applications. To facilitate the recycling of these nanosized adsorbents after treatment of polluted water, introduction of magnetism into nano-adsorbents can help with the recycling of adsorbents from the wastewater system via direct application of an external magnetic field. ${ }^{50}$
The first family of adsorbents discussed in this article is imparted with magnetic functionality in the architecture. Another common approach to instilling adsorption capability in nanocomposite adsorbents is the surface functionalization via introduction of functional groups such as carboxylate, hydroxyl, sulfate, and amino groups. ${ }^{51}$ These functional groups have been demonstrated to present heavy metal adsorption capacity by forming metal complexes or chelates. ${ }^{52.54}$ In nanocomposites, the surface functional groups can be feasibly introduced by applying polymers containing such desired groups. One particular example is the utilization of polyaniline (PANI) for $\mathrm{Cr}(\mathrm{VI})$ removal. ${ }^{44}$ Incorporation of PANI onto various substrates will be examined in this review. A related topic, the application of polyacrylic acid (PAA) for the removal of heavy metals, not only for $\mathrm{Cr}(\mathrm{VI})$ but also for $\mathrm{Pb}(\mathrm{II})$, is included. The different mechanisms involved in treatment of the two heavy metal ions will be discussed.

\section{Magnetic carbon nanocomposites for $\mathrm{Cr}(\mathrm{VI})$ adsorption from aqueous solution}

High surface area magnetic nanomaterials have attracted great attention for heavy metal removal because of the easy solid-liquid separation by applying an external magnetic field and favorable reusability. ${ }^{26,55}$ Zerovalent nano iron, polymorphic forms of iron oxides, and $\mathrm{FeOOH}$ are premier examples. Several methods are available to prepare such materials like physical, chemical, and biological approaches. ${ }^{56}$ The most accepted and used method is the chemical approach, including chemical co-precipitation, thermal decomposition, sol-gel, and electrochemical method. ${ }^{56}$ Under careful design and excellent experimental execution, iron containing nanomaterials can be synthesized with a smaller particle size and larger specific surface area than micro-sized and bulk iron compounds. $^{57}$ The more effective substrate dispersibility and higher reactivity of the iron-nanomaterials make these materials very attractive for $\mathrm{Cr}(\mathrm{VI})$ removal $^{58}$ However, easy agglomeration of these materials severely decreases the reactivity and limits the applications for environmental remediation. ${ }^{59}$ When deposited on suitable support materials, the dispersibility and stability of the iron nanomaterials can be greatly enhanced to render the modified materials highly sufficient for $\mathrm{Cr}(\mathrm{VI})$ removal. 
Carbon is often chosen as such a substrate because of its low cost, high specific surface area, and high stability. ${ }^{60,61}$ Common carbon nanomaterials include zero-dimensional carbon nanoparticles and nanospheres, one-dimensional carbon nanotubes (CNTs) and carbon nanofibers, two-dimensional graphene and carbon fabrics, and threedimensional carbon nanoclusters and carbon nanofoams. Sometimes, activation of carbon nanomaterials is needed to the significantly enlarge surface area and increase surface hydrophilicity, facilitating the diffusion and adhesion of pollutant molecules inside the adsorbent. When CNT is mixed with $\mathrm{K}_{2} \mathrm{Cr}_{2} \mathrm{O}_{7}$ at different $\mathrm{pH}$, the interaction between $\mathrm{Cr}(\mathrm{VI})$ and CNT is studied as a function of varied solution $\mathrm{pH}^{45}$ At $\mathrm{pH} 1$, carboxylation is found to occur after $\mathrm{Cr}(\mathrm{VI})$ interaction, with FTIR showing $3300 \mathrm{~cm}^{-1}$ from $\mathrm{O}-\mathrm{H}$ stretching, $1641 \mathrm{~cm}^{-1}$ from $\mathrm{C}=\mathrm{O}$ vibration, and peaks around $1020-1100 \mathrm{~cm}^{-1}$ due to the $\mathrm{C}-\mathrm{O}-\mathrm{C}$ stretching. At $\mathrm{pH}>2$, no such functionalization is observed. These oxygen species are also observed in X-ray photoelectron spectroscopy (XPS) spectra, with binding energy of $286.1 \mathrm{eV}$ attributed to $\mathrm{C}-\mathrm{O}$ moiety along with the existence of $\mathrm{Cr}(\mathrm{III})$ from reduced $\mathrm{Cr}(\mathrm{VI})$. From Raman measurement, the intensity of the D-band attributed to $\mathrm{sp}^{3} \mathrm{C}-\mathrm{C}$ bonds is increased while that of G-band attributed to $\mathrm{sp}^{2} \mathrm{C}=\mathrm{C}$ bonds is reduced after $\mathrm{Cr}(\mathrm{VI})$ treatment. The adsorption of $\mathrm{Cr}(\mathrm{VI})$ onto $\mathrm{CNT}$ follows a pseudo-first-order kinetic model with a rate constant of 0.0579 $\min ^{-1}$ at $\mathrm{pH} 1$. At $\mathrm{pH} 7$, the $\mathrm{Cr}(\mathrm{VI})$ adsorption follows a pseudo-secondorder model with a rate constant of $0.865 \mathrm{~g} \mathrm{mg}^{-1} \min ^{-1}$. The speculated interaction between $\mathrm{Cr}(\mathrm{VI})$ and $\mathrm{CNT}$ is illustrated in Fig. 1.

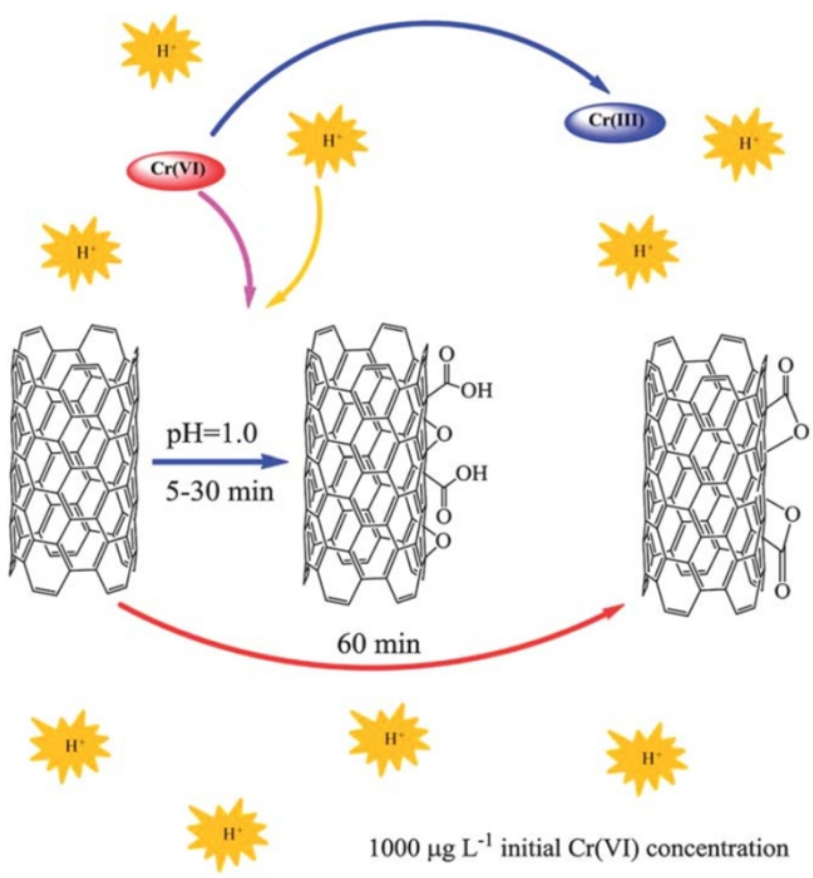

Fig. 1 Speculated interaction between $\mathrm{Cr}(\mathrm{VI})$ and $\mathrm{CNT}$ at $\mathrm{pH} 1$. Reproduced from Ref. 45 with permission from The Royal Society of Chemistry.

A similar study uses activated carbon fabric of $1500 \mathrm{~m}^{2} \mathrm{~g}^{-1}$ to react with $\mathrm{K}_{2} \mathrm{Cr}_{2} \mathrm{O}_{7}$ at different $\mathrm{pH}^{62}$ At high $\mathrm{Cr}(\mathrm{VI})$ concentration and low $\mathrm{pH}$, the fabric surface is etched. The adsorption of $\mathrm{Cr}(\mathrm{VI})$ follows a pseudo-first-order kinetic model with a rate constant of $0.0872 \mathrm{~min}^{-1}$, while the isotherm follows Langmuir model with a $q_{\max }$ of $5.59 \mathrm{mg} \mathrm{g}^{-1}$. After $\mathrm{Cr}(\mathrm{VI})$ adsorption, oxygenation is observed on the carbon surface, while $\mathrm{Cr}(\mathrm{III})$ is found on carbon surface via XPS.

While activated carbon materials have been widely attempted as adsorbents for environmental remediation, these materials often encounter difficulties during recycling. If combined with iron components, the hybrid carbon materials become the family of magnetic carbon adsorbents that have attracted increasing attention for heavy metal removal from wastewater. In one study, $\mathrm{Fe}(\mathrm{CO})_{5}$ is converted into $\mathrm{Fe}_{2} \mathrm{O}_{3}$ wires of $0.4-0.6 \mu \mathrm{m}$ supported on graphite particles. ${ }^{63}$ The submicron wires are further reduced by hydrogen gas treatment and used in aqueous $\mathrm{Cr}(\mathrm{VI})$ removal. The removal process is best fitted with pseudo-second order kinetic model with a rate constant $k_{\text {ad }}$ of $1.2 \mathrm{~g} \mathrm{mg}^{-1} \min ^{-1}$ and the adsorption capacity at equilibrium $q_{\mathrm{e}}$ of $0.52 \mathrm{mg} \mathrm{g}^{-1}$ at room temperature. While the $q_{\mathrm{e}}$ falls in the range of commercial $\alpha-\mathrm{Fe}_{2} \mathrm{O}_{3}\left(0.68 \mathrm{mg} \mathrm{g}{ }^{-1}\right),{ }^{64}$ the rate constant of this nanocomposite is much faster than that of existing adsorbents of $<0.5 \mathrm{~g}$ $\mathrm{mg}^{-1} \min ^{-1} .^{65}$ A similar endeavor employs graphene sheets as the anchoring sites to grow core/shell particles. ${ }^{10}$ Under high resolution tunneling electron microscope (HR-TEM) and selected area electron diffraction (SAED) scrutiny, the particles are found to have an $\mathrm{Fe}(0)$ core, an $\mathrm{Fe}_{2} \mathrm{O}_{3}$ inner-shell, and a $\mathrm{Si} / \mathrm{S}$ outer-shell which is beneficial for protection of iron core against acid erosion. The nanocomposite demonstrates $\mathrm{Cr}(\mathrm{VI})$ adsorption behavior similar to the submicron $\mathrm{Fe}_{2} \mathrm{O}_{3}$ wires with $k_{\mathrm{ad}}$ of $0.28 \mathrm{~g} \mathrm{mg}^{-1} \mathrm{~min}^{-1}$ and $q_{\mathrm{e}}$ of $1.03 \mathrm{mg} \mathrm{g}^{-1}$.

To further enhance the heavy metal adsorption performance of the magnetic carbon materials, surface modification with heteroatoms has been applied. Heteroatom doping can intrinsically alter the electronic state of the adsorbent, and potentially improve the interaction between the adsorbent and heavy metal ions. Nitrogen doped Fe@C particles have been prepared to demonstrate the effect for heavy metal adsorption. ${ }^{66}$ The sample is produced by mixing melamine, glucose, and iron salt, then carbonized at $800{ }^{\circ} \mathrm{C}$ under $\mathrm{N}_{2}$. Core-shell Fe@carbon particles are obtained in which both $\mathrm{Fe}_{3} \mathrm{O}_{4}$ and $\mathrm{Fe}(0)$ exist in the core phase. The existence of nitrogen in the annealed sample is illustrated by XPS with pyridinic $\mathrm{N}$, pyrrolic $\mathrm{N}$, quaternary $\mathrm{N}$, noxides, and chemisorbed $\mathrm{N}$ are present in the samples (Fig. 2). The $\mathrm{Cr}(\mathrm{VI})$ adsorption of the particles follows a pseudo-second-order model. The adsorption isotherm fits the Langmuir model, with a maximum adsorption capacity of $2001.4 \mathrm{mg} \mathrm{g}^{-1}$ in acidic solution.

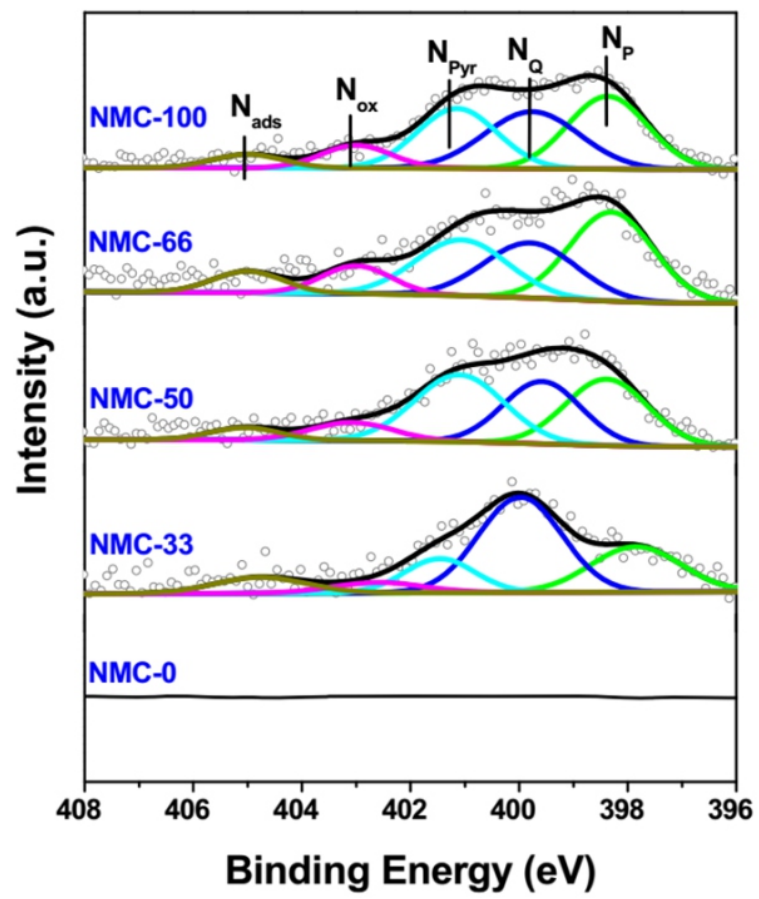

Fig. $2 \mathrm{~N}_{1 \mathrm{~s}}$ XPS spectra of Fe@C particles prepared from (melamine + glucose $+\mathrm{Fe}^{3+}$ ) and annealed at $800{ }^{\circ} \mathrm{C}$ under $\mathrm{N}_{2}$. Reproduced from Ref. 66 with permission from Elsevier. 
Fluorine doping is carried out by using poly(vinylidene fluoride) (PVDF) as the carbon source. ${ }^{67}$ The material has amorphous carbon coating surrounding iron cores. High $\mathrm{F}$ doping leads to increased $\mathrm{I}_{\mathrm{D}} / \mathrm{I}_{\mathrm{G}}$ ratio in the Raman spectra. The $\mathrm{Cr}(\mathrm{VI})$ adsorption isotherm fits the Langmuir model with a maximum adsorption capacity of $1423.4 \mathrm{mg} \mathrm{g}^{-1}$ in acidic solution. And simultaneous doping of nitrogen and fluorine can be realized by using both PVDF and melamine as the carbon source. ${ }^{68}$ After doping with the two elements, the carbonized graphene shows a great deal of amorphous structure. The Fe@C particles show Langmuir model $\mathrm{Cr}(\mathrm{VI})$ adsorption isotherm with a $q_{\max }$ of $740.7 \mathrm{mg} \mathrm{g}^{-1}$, less than the samples doped with either nitrogen or fluorine only.

When preparing magnetic carbon adsorbents, carbon sources have been demonstrated crucial for the properties of the synthesized magnetic carbon. Many carbon precursors have been selected for fabricating magnetic carbons, such as polymer, ${ }^{69}$ cotton, ${ }^{70}$ furfuryl alcohol, ${ }^{71}$ rice husk, ${ }^{72}$ cellulose ${ }^{73}$ and so on. In one study, equal amounts of cellulose and $\mathrm{Fe}\left(\mathrm{NO}_{3}\right)_{3} \cdot 9 \mathrm{H}_{2} \mathrm{O}$ are dissolved in ethanol solution, then the dried material is carbonized at $800{ }^{\circ} \mathrm{C}$ under $\mathrm{N}_{2}$ to present submicron spherical, core/shell Fe@C particles with high content of $\mathrm{Fe}(0)$ in the core phase. ${ }^{73}$ At $\mathrm{pH} 1$, the maximum $\mathrm{Cr}(\mathrm{VI})$ adsorption capacity $q_{\max }$ is $327.5 \mathrm{mg} \mathrm{g}^{-1}$. During the adsorption at acidic condition, $\mathrm{Fe}(0)$ is oxidized to $\mathrm{Fe}(\mathrm{III})$ and $\mathrm{Cr}(\mathrm{VI})$ is reduced to $\mathrm{Cr}(\mathrm{III})$. The $\mathrm{Cr}(\mathrm{III})$ is positively charged and adsorbed on the carbon surface by electrostatic force. At neutral condition, $\mathrm{Cr}(\mathrm{OH})_{3}$ and $\mathrm{Fe}(\mathrm{OH})_{3}$ are precipitated and deposited on the adsorbent (Fig. 3). A prior study utilizes a lower portion of cellulose when preparing $\mathrm{Fe} / \mathrm{C}$ spheres from the same precursors. $^{74}$ In this case, the $\mathrm{Fe} @ \mathrm{C}$ particles are smaller than the aforementioned example, while the maximum $\mathrm{Cr}(\mathrm{VI})$ adsorption capacity $q_{\max }$ is $278.8 \mathrm{mg} \mathrm{g}^{-1}$.

Other biomass has been employed in the synthesis of magnetic carbon adsorbents for heavy metal removal from wastewater. Activated sludge is mixed with iron salt, then treated with ultrasonication to release cytoplasm substance as carbon source. ${ }^{75}$ The material is annealed at $800{ }^{\circ} \mathrm{C}$ or higher under $\mathrm{N}_{2}$ to yield $\mathrm{Fe} @ \mathrm{C}$ particles with primary $\mathrm{Fe}(0)$ and $\mathrm{Fe}_{3} \mathrm{C}$ core phase wrapped by a carbon layer. The $\mathrm{Cr}(\mathrm{VI})$ adsorption has a maximum capacity of $203 \mathrm{mg} \mathrm{g}^{-1}$ and follows pseudosecond-order kinetic model with a rate constant of $1.11 \mathrm{mg}^{-1} \mathrm{~L} \mathrm{~min}^{-1}$.

In such $\mathrm{Fe} @ \mathrm{C}$ particles, the iron phase and the carbon phase can

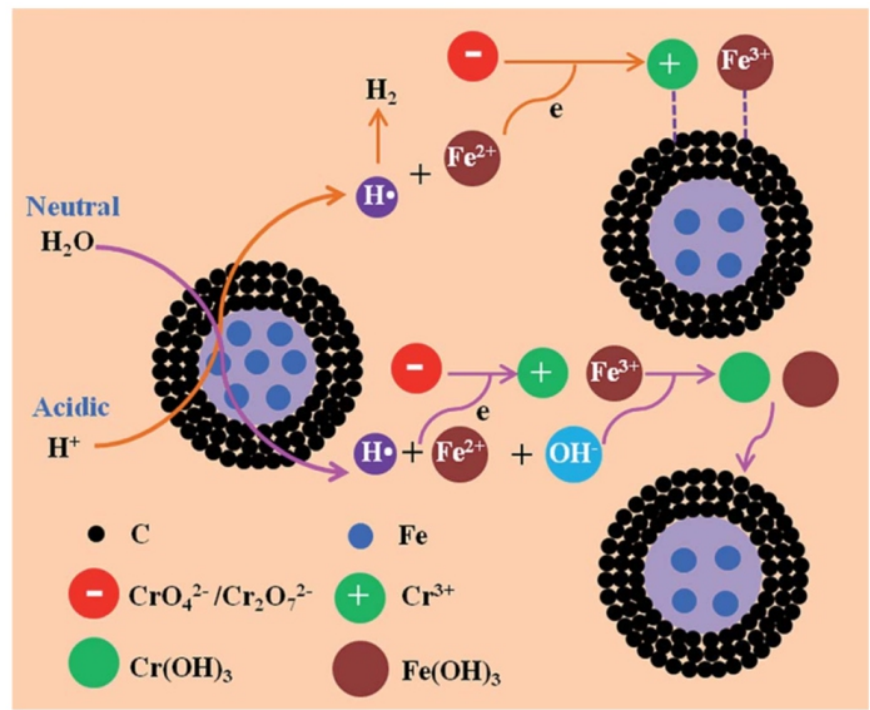

Fig. $3 \mathrm{Cr}(\mathrm{VI})$ removal mechanism for the Fe@C spherical particles prepared from (cellulose $+\mathrm{Fe}^{3+}$ ) followed by annealing at $800{ }^{\circ} \mathrm{C}$ under $\mathrm{N}_{2}$. Reproduced from Ref. 73 with permission from The Royal Society of Chemistry.
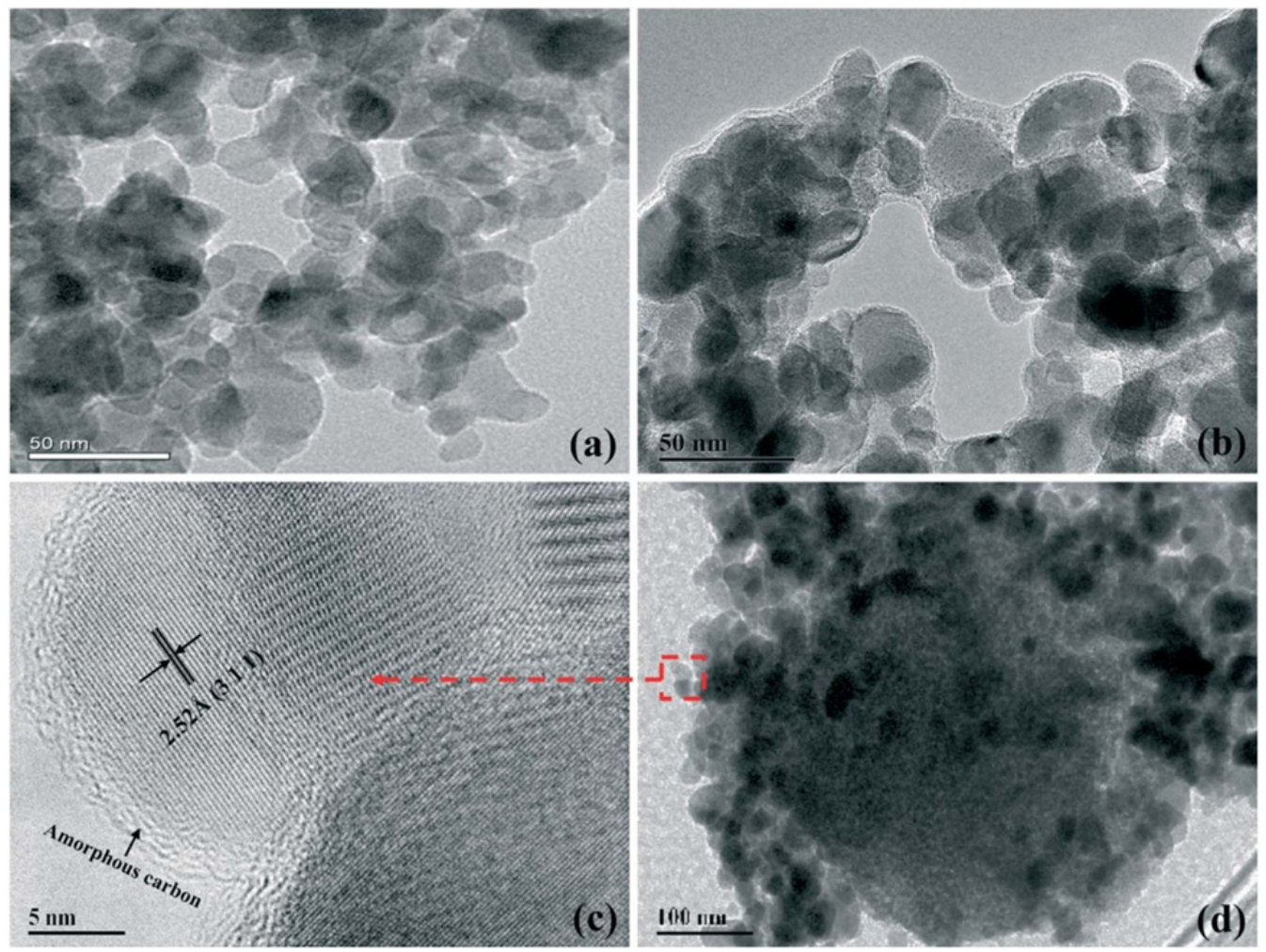

Fig. 4 TEM images of (a) magnetite, (b) chitosan coated magnetite, (d) annealed Fe/C hybrid, and (c) HRTEM of annealed Fe@C particle prepared from $\left(\mathrm{Fe}+\mathrm{PS}+\right.$ chitosan) and annealed at $500{ }^{\circ} \mathrm{C}$ under $\mathrm{N}_{2}$. Reproduced from Ref. 76 with permission from Engineered Science Publisher. 
be further strengthened by applying covalent bonding before carbonization for better coverage of the core phase with the stable carbon layer. In one case, magnetite $\left(\mathrm{Fe}_{3} \mathrm{O}_{4}\right)$ particles of $20-30 \mathrm{~nm}$ (Fig. 4a) are produced from $\mathrm{Fe}(\mathrm{II})$ and $\mathrm{Fe}(\mathrm{III})$ salts at 1:2 ratio. ${ }^{76}$ After separated from reaction media, the particles are mixed with chitosan molecules which show as a layer covering the magnetite particles (Fig. $4 \mathrm{~b})$. The chitosan-covered magnetite particles are then reacted with epoxy-PS microspheres to form covalent bonding with chitosan. Annealing at $500{ }^{\circ} \mathrm{C}$ under $\mathrm{N}_{2}$ provides the carbon submicron sphere originated from PS whose surface is clustered with Fe@C particles (Fig. 4d). The HRTEM image of the small particles unveils a core/shell structure comprised of a crystalline core and an amorphous carbon layer (Fig. 4c). The lattice distance of $0.252 \mathrm{~nm}$ is assigned to the (311) crystallographic planes of magnetite (PDF\#65-3107). ${ }^{77}$ The $\mathrm{Cr}(\mathrm{VI})$ removal performance is tested on the formed Fe@C composite. The $\mathrm{Cr}(\mathrm{VI})$ adsorption is fitted with pseudo-second-order model with the initial adsorption rate of $7.106 \mathrm{mg} \mathrm{g}^{-1} \mathrm{~min}^{-1}$ and Langmuir isotherm model with a $q_{\mathrm{t}}$ of $9.52 \mathrm{mg} \mathrm{g}^{-1}$. No $\mathrm{Cr}(\mathrm{VI})$ reduction is found, indicating magnetite particles do not possess the capacity for $\mathrm{Cr}(\mathrm{VI})$ reduction. The similar manipulation is applied without the addition of chitosan. ${ }^{78}$ $\mathrm{Fe}^{3+}$ is added to the epoxy-PS microsphere suspension, followed by annealing at $500{ }^{\circ} \mathrm{C}$ under $\mathrm{H}_{2} / \mathrm{Ar}$ to produce $\mathrm{Fe} @ \mathrm{C}$ composite particles of $\sim 30 \mathrm{~nm}$ in size. Now, $\mathrm{Fe}(0)$ is found in the core phase that facilitates the reduction of $\mathrm{Cr}(\mathrm{VI})$ to $\mathrm{Cr}$ (III) (Fig. 5).

Synthetic polymer polyvinyl alcohol (PVA) is directly mixed with iron salt to prepare Fe@C composite. ${ }^{79}$ Carbon encapsulated magnetic particles of $15 \mathrm{~nm}$ are produce that contain $\mathrm{Fe}(0)$ core, Fig. 6. The lattice distance of $0.21 \mathrm{~nm}$ corresponding to the (110) plane of $\alpha-\mathrm{Fe}$ crystal is depicted, ${ }^{80}$ along with the outer lattice fringe with a d-spacing of $0.20 \mathrm{~nm}$ assigned to the (002) plane of graphite. ${ }^{81}$ Other than particulate materials, Fe@C composite can be synthesized as fibers. Here, polyacrylonitrile and $\mathrm{Fe}^{3+}$ salts are dissolved and charged to electrospinning to produce submicron fibers. ${ }^{82}$ After annealing at $800{ }^{\circ} \mathrm{C}$ under $\mathrm{N}_{2}$ to form fibers of $230-420 \mathrm{~nm}$ in diameter, the hybrids feature carbon fibers whose surface is attached with Fe@C particles. X-ray diffraction (XRD) analysis of these materials illustrates the existence of $\alpha-\mathrm{Fe}, \gamma-\mathrm{Fe}, \mathrm{Fe}_{3} \mathrm{C}$, and $\mathrm{FeO}$ (Fig. 6a). In Raman curves, the ratio of the intensities of defective degree $R=I_{\mathrm{D}} / I_{\mathrm{G}}$ demonstrates that more iron content decreases the in-plane graphitic crystallite (Fig. 6b). The fibers with high iron content show a maximum $\mathrm{Cr}(\mathrm{VI})$ adsorption capacity $q_{\max }$ of $43.18 \mathrm{mg} \mathrm{g}^{-1}$.
Cotton fabric has been utilized as the carbon support to prepare $\mathrm{Fe} @ \mathrm{C}$ particles. In the preparation, $\mathrm{Fe}\left(\mathrm{NO}_{3}\right)_{3}$ solution is used to soak cotton fabric, then annealed at $>800{ }^{\circ} \mathrm{C}$ under $\mathrm{N}_{2}$ either in furnace ${ }^{83}$ or in a microwave oven. ${ }^{84}$ After annealing, cotton fabric becomes fibrous structure uniformly decorated with particles tens of $\mathrm{nm}$ in size. Via HRTEM, XRD, and XPS measurements, the particles are determined to have $\mathrm{Fe} @ \mathrm{C}$ microstructure. The core phase is primarily $\mathrm{Fe}(0)$ and $\mathrm{Fe}_{3} \mathrm{C}$ while the carbon shell is a few nm thick. The graphitization proceeds as follows: thermal decomposition of $\mathrm{Fe}\left(\mathrm{NO}_{3}\right)_{3}$ to form iron oxide nanoparticles, then carbothermal reduction of iron oxide to produce $\mathrm{Fe}_{3} \mathrm{C}$ nanoparticles. $\mathrm{Fe}_{3} \mathrm{C}$ is in liquid state at $800{ }^{\circ} \mathrm{C}$ so nanoparticles can freely migrate on carbon matrix to catalyze the reaction of amorphous carbon conversion to graphitized carbon covering iron core. After the conversion, hollow tubular structure is formed with the mesoporous wall. The Fe@C composite demonstrates a Cr(VI) adsorption capacity of $3.74 \mathrm{mg} \mathrm{g}^{-1}$ and a rate constant of $0.30 \mathrm{~g} \mathrm{mg}^{-1} \mathrm{~min}^{-1}$.

\section{Polymer functionalized composites for heavy metal adsorption}

One effective way to remediate the $\mathrm{Cr}(\mathrm{VI})$ contamination is the reduction of $\mathrm{Cr}(\mathrm{VI})$ to $\mathrm{Cr}(\mathrm{III})$. Certain adsorbents can simultaneously

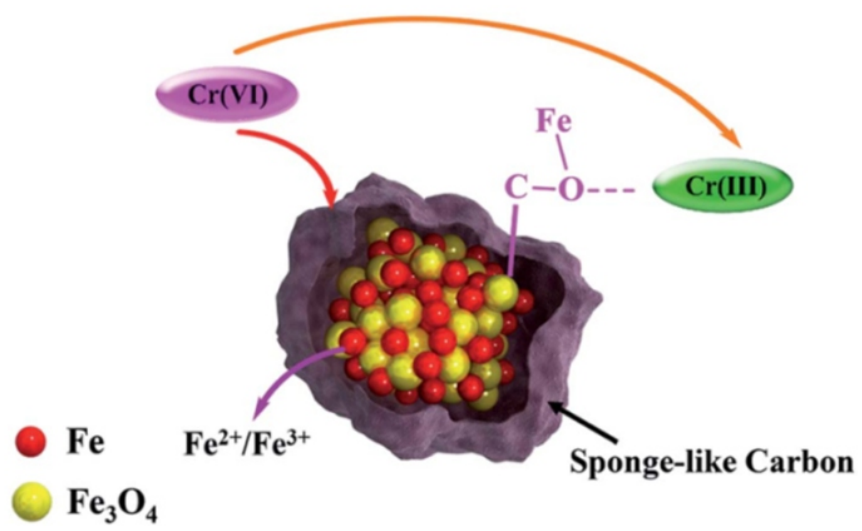

Fig. 5 Schematic for the $\mathrm{Cr}(\mathrm{VI})$ removal mechanism by $\mathrm{Fe} @ \mathrm{C}$ composite particles prepared from ( $\mathrm{Fe}^{3+}+\mathrm{PS}$ sphere) and annealed at $500{ }^{\circ} \mathrm{C}$ under $\mathrm{H}_{2} /$ Ar. Reproduced from Ref. 78 with permission from The Royal Society of Chemistry.
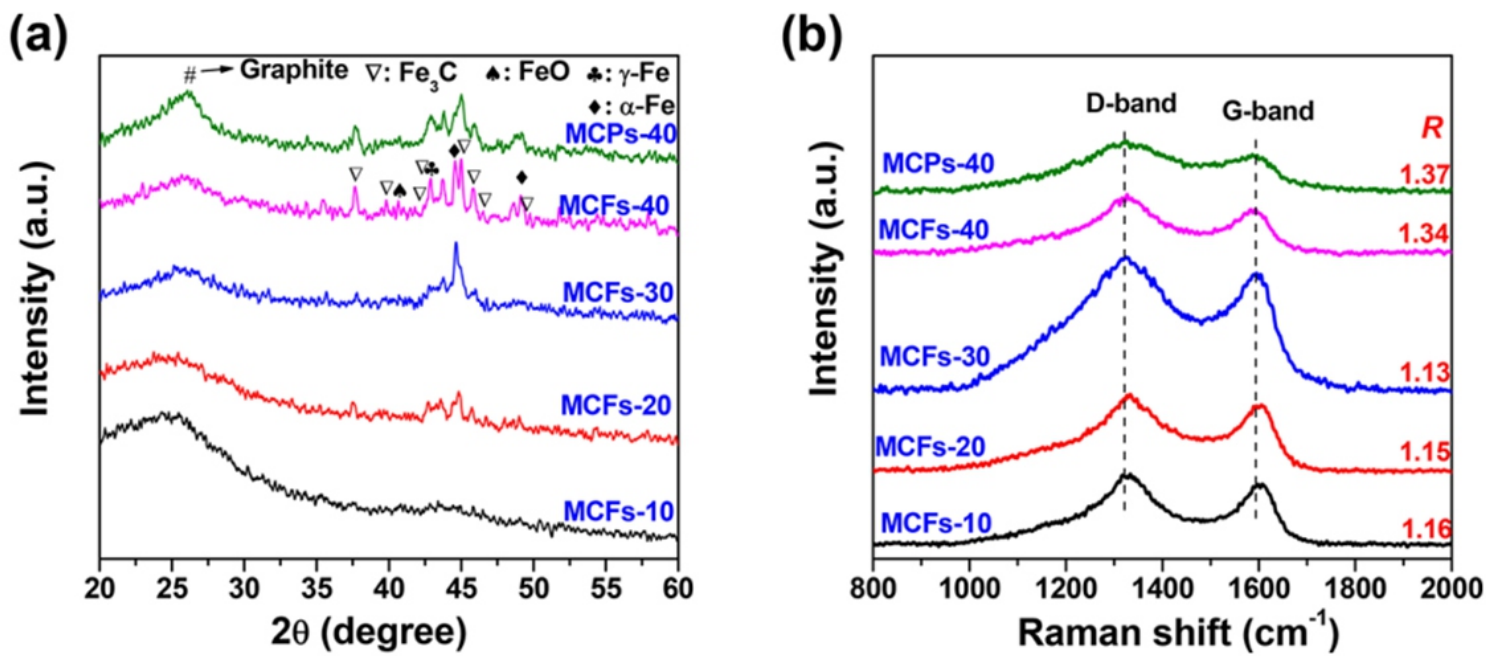

Fig. 6 (a) XRD and (b) Raman spectra of Fe@C particles decorated on carbon fiber prepared from (PAN + Fe ${ }^{3+}$ ) via electrospinning followed by annealing at $800{ }^{\circ} \mathrm{C}$ under $\mathrm{N}_{2}$. Reproduced from Ref. 79 with permission from The Royal Society of Chemistry. 
adsorb and reduce $\mathrm{Cr}(\mathrm{VI})$ to $\mathrm{Cr}(\mathrm{III})$, thus have been intensively investigated for the treatment of $\mathrm{Cr}(\mathrm{VI})$ contaminants. To reduce $\mathrm{Cr}(\mathrm{VI})$ to $\mathrm{Cr}$ (III), these adsorbents become electron donors during the adsorption process. $\mathrm{Fe}(0), \mathrm{Fe}(\mathrm{II})$ and polymer are among the widely studied as the electron donors for the reduction of $\mathrm{Cr}(\mathrm{VI})$. Polyaniline (PANI) receives increasing attention for heavy metal removal due to the high removal efficiency. For $\mathrm{Cr}(\mathrm{VI})$ removal, PANI is a specifically good adsorbent due to its good reduction behavior. ${ }^{85}$ PANI has three different structures, i.e., leucoemeraldine (LB), emeraldine (EB) and pernigraniline $(\mathrm{PB})$. The electron transfer from the $\mathrm{LB}$ or $\mathrm{EB}$ state to $\mathrm{PB}$ state is a facile process that greatly assists the effective $\mathrm{Cr}(\mathrm{VI})$ reduction to $\mathrm{Cr}(\mathrm{III})$.

Powder and film are the two pure PANI forms that can be used. Films are relatively difficult to prepare in large quantity, and have small specific surface area that limits the adsorption capacity when used for $\mathrm{Cr}(\mathrm{VI})$ removal. Powders have large specific surface area and can be easily produced in bulk. But recycling of powders is a challenge. Coating of PANI onto reusable substrates has been investigated as a solution to effectively using PANI for $\mathrm{Cr}(\mathrm{VI})$ removal. Magnetite particles are coated with PANI via the surface initiated polymerization route. ${ }^{34}$ After polymerization, the particle surface becomes rougher (Fig. 7c), and a thin PANI layer is visible surrounding the particles (Fig. 7d). The calculated $d$-spacing values of $1.92,2.40,2.87,3.73$, and $4.04 \AA$ correspond to the (220), (311), (400), (422), and (511) crystallographic planes of the spinel phase $\mathrm{Fe}_{3} \mathrm{O}_{4}$. The results indicate that magnetite particles have been successfully embedded in the PANI without dissolution in acid. In FTIR, the strong absorption peaks at 1560 and $1482 \mathrm{~cm}^{-1}$ correspond the $\mathrm{C}=\mathrm{C}$ stretching vibration of $\mathrm{N}=\mathrm{Q}=\mathrm{N}$ (Q- quinoid ring) and N-B-N (B-benzenoid ring), respectively. The peak at $1292 \mathrm{~cm}^{-1}$ is related to $\mathrm{C}-\mathrm{N}$ stretching vibration of the benzenoid ring, while the peak at $1238 \mathrm{~cm}^{-1}$ is assigned to $\mathrm{C}-\mathrm{H}$ stretching vibration of the quinoid ring. These characteristic peaks prove that PANI in the synthesized magnetite/PANI composite appears as EB state. The N1s XPS spectra can be deconvoluted into curves around 398.1, 399.0, 400.1 , and $401.8 \mathrm{eV}$, respectively. The first two regions are assigned to the undoped imine $(-\mathrm{N}=)$ and amine $(-\mathrm{NH}-)$ groups, respectively. The last two are attributed to the doped imine and amine groups, respectively. Equal proportions of imine and amine components show the EB state of PANI.

The EB form PANI in the synthesized composite adsorbent is partially oxidized to the PB form after adsorption of $\mathrm{Cr}(\mathrm{VI})$, while $\mathrm{Cr}(\mathrm{VI})$ is reduced to $\mathrm{Cr}(\mathrm{III})$ (Fig. 8). The maximum adsorption capacity is $16.7 \mathrm{mg} \mathrm{g}^{-1}$. The magnetic hysteresis measurements of the composite before and after adsorption of $\mathrm{Cr}(\mathrm{VI})$ reveal that PANI has effectively protected magnetite particles from dissolution and aggregation. Another study uses $\mathrm{Fe}(0) @ \mathrm{C}$ particles as the magnetic support to coat PANI. ${ }^{86}$ The produced particles are $200 \mathrm{~nm}$ in diameter with a PANI layer of $20 \mathrm{~nm}$. At $\mathrm{pH} \mathrm{1}$, the material has a $\mathrm{Cr}(\mathrm{VI})$ adsorption capacity $q_{\max }$ of $508 \mathrm{mg} \mathrm{g}^{-1}$.

PANI is mixed with ethyl cellulose solution. ${ }^{35}$ From SEM images, the rough surface of cellulose particles is covered with PANI and thus becomes smooth. With increasing PANI loading, the $\mathrm{Cr}(\mathrm{VI})$ removal capacity increases. In acidic solution, amine groups in PANI are protonated to become positively charged. More PANI loading provides higher positive charge density on composite surface that can attract more negatively charged chromate ions $\left(\mathrm{CrO}_{4}^{2-}\right.$ and $\left.\mathrm{HCrO}_{4}^{-}\right)$. With a

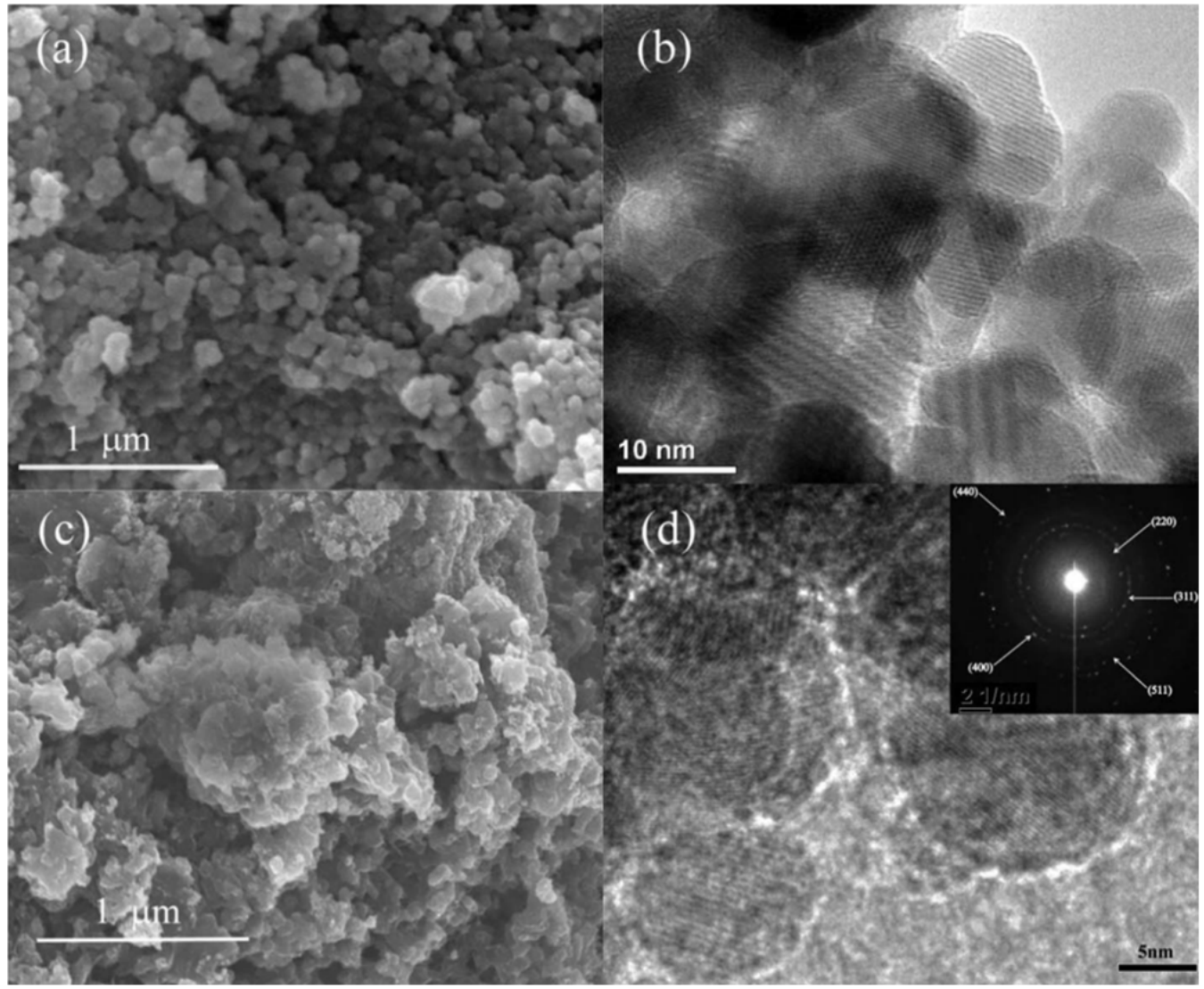

Fig. 7 (a) SEM and (b) TEM images of magnetite particles; (c) SEM image and HRTEM image and SAED pattern (inset picture) of synthesized $\mathrm{Fe}_{3} \mathrm{O}_{4} @$ PANI. Reproduced from Ref. 34 with permission from The Royal Society of Chemistry. 
high redox potential of $1.33 \mathrm{eV}$, hydrogen chromate is easily reduced to $\mathrm{Cr}$ (III) in acidic solution by the active groups of the adsorbent. The adsorption of $\mathrm{Cr}(\mathrm{VI})$ is accompanied by the increased ratio of intensity at $1580 \mathrm{~cm}^{-1}$ (imine) to $1482 \mathrm{~cm}^{-1}$ (amine), indicating the amine group has been oxidized to imine by $\mathrm{Cr}(\mathrm{VI})$. The intensity of $1053 \mathrm{~cm}^{-1}$ also decreases after $\mathrm{Cr}(\mathrm{VI})$ adsorption, revealing the oxidation of hydroxyl group to carboxyl group on cellulose. XPS spectrum of $\mathrm{Cr}_{2 \mathrm{p}}$ illustrates the no $\mathrm{Cr}(\mathrm{VI})$ is observed after adsorption, only presence of $\mathrm{Cr}(\mathrm{III})$ (binding energy of 576.0 and $585.2 \mathrm{eV}$ ). The $\mathrm{Cr}(\mathrm{VI})$ adsorption by the composite can be suitably fitted with a pseudo-second-order model which indicates a chemical adsorption process. A $k_{\text {ad }}$ of $0.0139 \mathrm{~g} \mathrm{mg}^{-1}$ $\min ^{-1}$ can be obtained for the $20 \%$ PANI loaded sample. The $\operatorname{Cr}(\mathrm{VI})$ reduction is assigned as the rate-limiting step during the process. The Langmuir isotherm model can better fit the adsorption with adsorption capacity $q_{\max }$ of $38.76 \mathrm{mg} \mathrm{g}^{-1}$. The isoelectric point of PANI is around $\mathrm{pH}$ 4.0. Above this $\mathrm{pH}$, PANI is negatively charged through the deprotonation of amine. $\mathrm{Cr}$ (III) species are positively charged in this $\mathrm{pH}$ range. So the electrostatic attraction between the two induces $\mathrm{Cr}$ removal. $\mathrm{EC}$ has a lower isoelectric point of $\mathrm{pH} 2.5$, thus expanding the range for electrostatic attraction of positive $\mathrm{Cr}$ (III) ions.

Amine and hydroxyl groups containing bacteria substance is mixed with aniline and undergoes polymerization. ${ }^{87}$ The hybrid material has diameter of $100 \mathrm{~nm}$ and length of $300 \mathrm{~nm}$. The IV type isotherm indicates the mesoporous structure with BET value $40-53 \mathrm{~m}^{2} \mathrm{~g}^{-1}$. The PANI is in the EB state, demonstrated by FTIR and XPS. The maximum $\mathrm{Cr}(\mathrm{VI})$ adsorption capacity is $913.2 \mathrm{mg} \mathrm{g}^{-1}$. Bacteria are used as the support for the synthesis of PANI-coated particles of $\sim 400 \mathrm{~nm}^{88}$ After drying, the cell is broken to release cytoplasmic substances to leave the PANI layer porous that permits the permeation of $\mathrm{Cr}(\mathrm{VI})$. The maximum adsorption capacity is $835 \mathrm{mg} \mathrm{g}^{-1}$. Carbon fiber is used to coat PANI. ${ }^{89}$ The maximum adsorption capacity at equlibrium $q_{\mathrm{e}}$ is 18.1 $\mathrm{mg} \mathrm{g}^{-1}$ and a pseudo-second-order kinetic rate $k_{\text {ad }}$ of $0.06 \mathrm{~g} \mathrm{mg}^{-1} \mathrm{~min}^{-1}$.
FTIR study demonstrates that the EB form has been oxidized to PB while XPS spectrum shows all $\mathrm{Cr}(\mathrm{VI})$ has been reduced to $\mathrm{Cr}$ (III) upon adsorption onto CF/PANI. Regeneration of the adsorbent is carried out by soaking in $0.1 \mathrm{M} \mathrm{HCl}$ solution.

Other than PANI, other polymers demonstrate Cr(VI) adsorption behavior when coated on support materials. Magnetite particles are coated with polyacrylic acid (PAA) via in situ polymerization. ${ }^{90}$ The magnetite@PAA particles are furhter modified to form magnetite@PAA- $\mathrm{NH}_{2}$. At $\mathrm{pH} \mathrm{3}$, the $\mathrm{Cr}(\mathrm{VI})$ removal capacity can reach $24 \mathrm{mg} \mathrm{g}^{-1}$. When the solution $\mathrm{pH}$ is above than 5 , the adsorption is impeded. The maximum adsorption capacity at equlibrium $q_{\mathrm{e}}$ by the adsorption isothermal study according to the Langmuir model is $9.8 \mathrm{mg} \mathrm{g}^{-1}$. Ethyl cellulose is coated with polyethylenimine (PEI). ${ }^{47}$ The composite material performs $\mathrm{Cr}(\mathrm{VI})$ removal capacitance in a wide $\mathrm{pH}$ range, with capacity decreased at increasing $\mathrm{pH}$. The maximum adsorption capacity calculated by the adsorption isothermal study according to the Langmuir model is 36.8 $\mathrm{mg} \mathrm{g}^{-1}$. During the adsorption, protons are consumed, related to the protonation of amine groups and the reduction of $\mathrm{Cr}(\mathrm{VI})$. The adsorbed $\mathrm{Cr}$ species is shown to be $\mathrm{Cr}$ (III) by XPS, no $\mathrm{Cr}(\mathrm{VI})$ is observed. Imine and amine groups are observed for PEI. Positively charged amine groups interact with the negative $\mathrm{Cr}(\mathrm{VI})$ ions, while $-\mathrm{OH}$ groups act as electron donors for the $\mathrm{Cr}(\mathrm{VI})$ reduction by oxidation to carboxyl groups under low $\mathrm{pH}$ (Fig. 9). Upon the reduction of $\mathrm{Cr}(\mathrm{VI})$ and increasing $\mathrm{pH}, \mathrm{Cr}^{3+}$ ions form $\mathrm{Cr}(\mathrm{OH})_{3}$ precipitate, favorably adsorbed by the composit adsorbent. The synergistic activities of both amine group of PEI and hydroxyl group of EC contribute to the high $\mathrm{Cr}(\mathrm{VI})$ removal performance.

The strategy of using polymer functionalized nanocomposites for the removal of heavy metal ions from wastewater is experimented with $\mathrm{Pb}$ (II). The difference between $\mathrm{Pb}$ (II) and $\mathrm{Cr}(\mathrm{VI})$ is that $\mathrm{Pb}$ (II) is positively charged in solution, so anionic polymers can exert electrostatic interaction. Lignin is grafted PAA via in situ polymerization, then

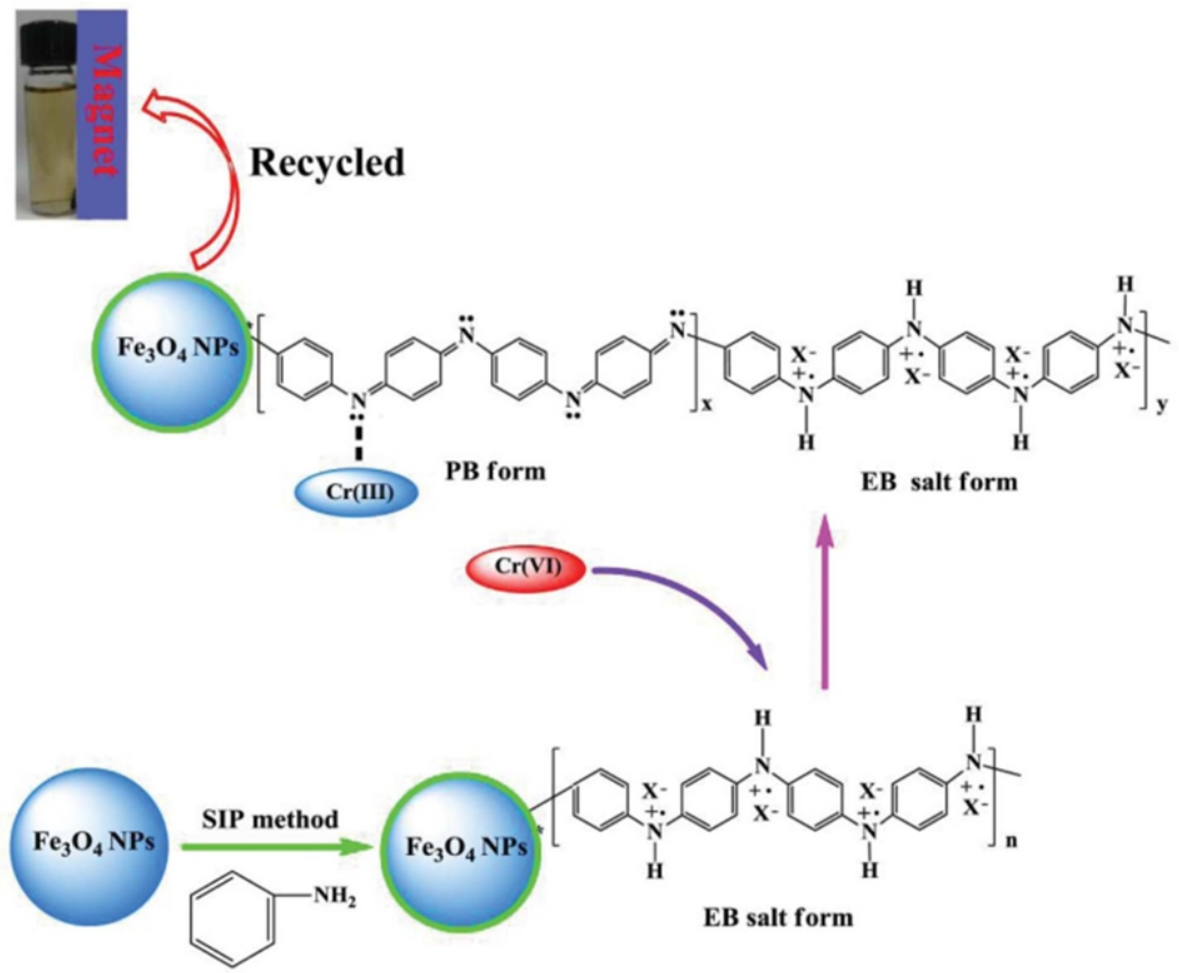

Fig. 8 Proposed mechanism of $\mathrm{Cr}(\mathrm{VI})$ removal by magnetite@PANI nanocomposites (X represents doping acid PTSA). Reproduced from Ref. 34 with permission from The Royal Society of Chemistry. 
dispersed with organo-montmorillonite. ${ }^{91}$ The composite has a $\mathrm{Pb}$ (II) adsorption capacity $q_{\mathrm{e}}$ of $1.19 \mathrm{mmol} \mathrm{\textrm {g } ^ { - 1 }}$. The in situ polymerization method can be used to graft PAA inside the pores of alumina by absorbing acrylic acid inside alumina followed by polymerization. ${ }^{92}$ This way, the high specific surface area of the mesoporous support can be fully utilized. The nanocomposite is tested the $\mathrm{Pb}$ (II) adsorption performance. ${ }^{93}$ The process follows a pseudo-second-order model with a rate constant of $0.215 \mathrm{~g} \mathrm{mg}^{-1} \mathrm{~min}^{-1}$, and a Langmuir-Freundlich model with a maximum adsorption capacity $q_{\max }$ of $204 \mathrm{mg} \mathrm{g}^{-1}$. The calculated adsorption free energy $E$ is $5.20 \mathrm{~kJ} \mathrm{~mol}^{-1}$, indicating a physical process. When neutralized acrylic acid is adsorbed onto alumina surface followed by in situ polymerization, a monolayer PAA coverage is obtained in the alumina/PAA composite. ${ }^{94}$ The process can be determined simiquantitative FTIR measurement. The sharp peak at $1391 \mathrm{~cm}^{-1}$ is assigned to the $-\mathrm{COO}^{-}$symmetric stretching vibration of PAA (Fig. 10). By increasing added acrylic acid monomer, a monolayer PAA can be obtained. Beyond the monolayer PAA coverage, no additional PAA can be adsorbed on alumina. The nanocomposite has $\mathrm{Pb}$ (II) adsorption capacity of $0.315 \mathrm{mmol} \mathrm{g}^{-1}$.

\section{Conclusions}

Various nanocomposites have been developed for the environmental remediation against heavy metal pollution. Many attempts have focused on the removal of $\mathrm{Cr}(\mathrm{VI})$ from wastewater. Two major groups of composite materials have been discussed. The first is the magnetic carbon family. A variant of carbon sources can be used in the synthesis of magnetic carbon composite materials, including cellulose, chitosan, sludge, synthetic polymers and carbon fabric. The synthesis of these materials is usually carried out in two major steps, mixing iron and carbon sources followed by annealing at high temperatures. Under reported experimental conditions, the synthesized materials have a core/shell structure of Fe@C. Depending on the individual preparation conditions, iron species in the core phase can exist in oxide, elemental, carbide, or combination of the above. The carbon shell not only prevents the Fe nanoparticles from aggregation, but also protects the core phase from dissolution or oxidation when elemental/carbide $\mathrm{Fe}$ exists. The reduced $\mathrm{Fe}$ species facilitate the reduction of $\mathrm{Cr}(\mathrm{VI})$ to $\mathrm{Cr}(\mathrm{III})$, which easily precipitates under neutral $\mathrm{pH}$. The other major group of nanocomposites is the polymer functionalized adsorbents.

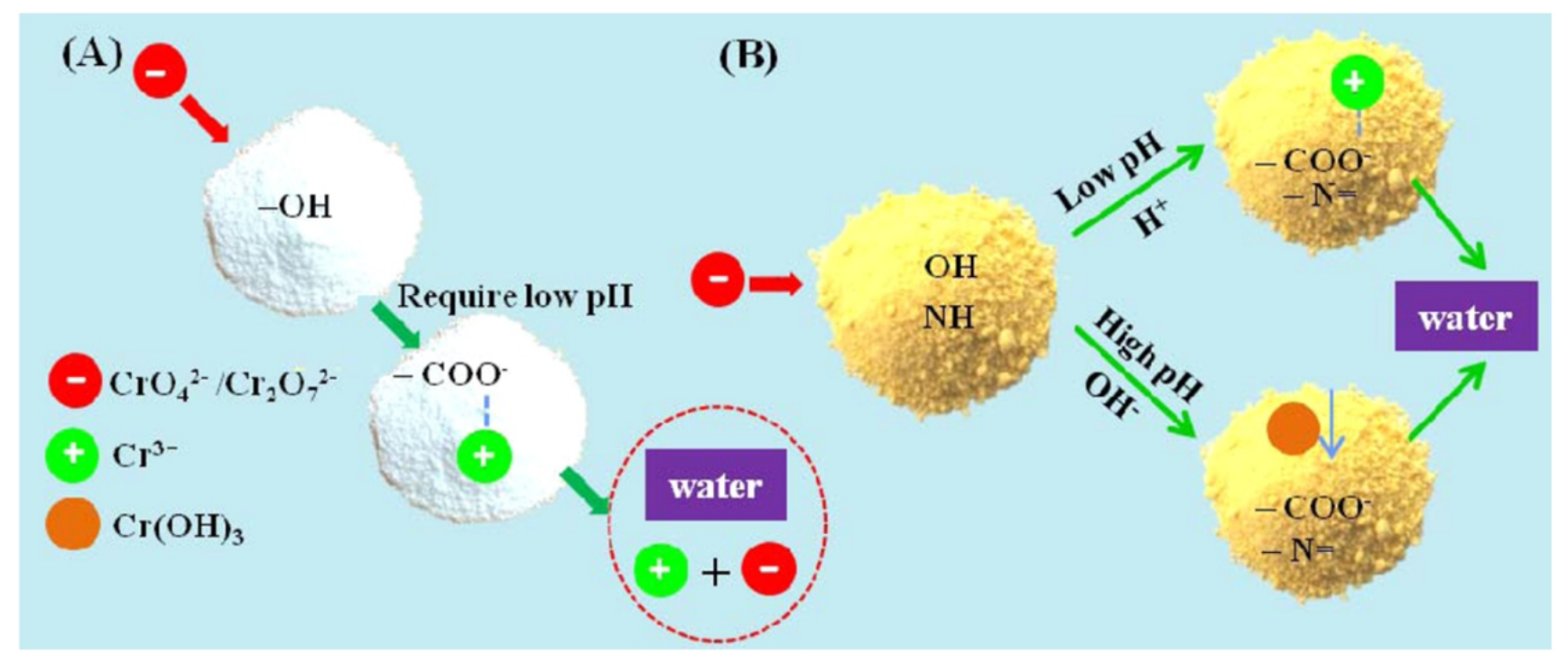

Fig. 9 Proposed mechanism of Cr(VI) adsorption by cellulose@PEI. Reproduced from Ref. 47 with permission from The American Chemical Society.

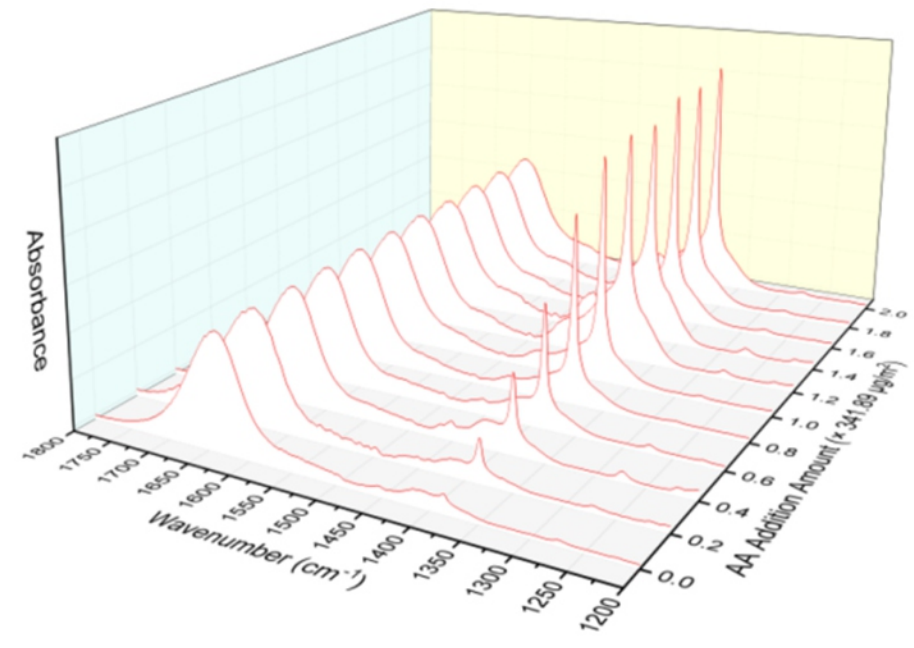

Fig. 10 FTIR spectra of alumina/PAA nanocomposites with different acrylic acid loadings. Reproduced from Ref. 94 with permission from The American Chemical Society. 
PANI is particularly employed for the removal of $\mathrm{Cr}(\mathrm{VI})$ because this redox polymer can also reduce $\mathrm{Cr}(\mathrm{VI})$ to $\mathrm{Cr}(\mathrm{III})$. On the other hand, functional groups such as amine and imine groups in PANI are shown to interact with $\mathrm{Cr}(\mathrm{VI})$ or $\mathrm{Cr}(\mathrm{III})$ to extract $\mathrm{Cr}$ from solution. Other polymers with like functional groups have been tested for $\mathrm{Cr}(\mathrm{VI})$ adsorption with limited success. The similar strategy of preparing polymer/support nanocomposite has been applied to produce PAA functionalized materials for adsorption of $\mathrm{Pb}$ (II) because positively charged $\mathrm{Pb}$ (II) can interact with anionic PAA in solution. In situ polymerization of acrylic acid in the presence of support is a facile process for the synthesis of the nanocomposites. Under controlled conditions, polymerization can take place inside mesoporous support materials to fully utilize the high specific surface area of the support. These two major adsorbent families discussed in this review both provide greatly promising performance. A few sample materials are worthy scale-up scrutiny for practical applications. Particular attention should be paid to compare the recycling capacitance of an adsorbent in a real-world situation, as well as the production cost analysis. Also the wastewater treatment facility requirement should be considered if the magnetic carbon is to be applied.

\section{Reference}

1. J. Trujillo-Reyes, J. R. Peralta-Videa and J. L. Gardea-Torresdey, J. Hazard Mater., 2014, 280, 487-503.

2. E. K. Wujcik, N. J. Londono, S. E. Duirk, C. N. Monty and R. I. Masel, Chemosphere, 2013, 91, 1176-1182.

3. E. K. Wujcik, S. E. Duirk, G. G. Chase and C. N. Monty, Sensors A ctuators B Chem., 2016, 223, 1-8.

4. D. Fialova, M. Kremplova, L. Melichar, P. Kopel, D. Hynek, V. Adam and R. Kizek, Materials, 2014, 7, 2242-2256.

5. O. Olanipekun, A. Oyefusi, G. M. Neelgund and A. Oki, Spectrosc., 2014, 118, 857-860.

6. M. Shirani, A. Semnani, S. Habibollahi and H. Haddadi, J. Anal. Atomic Spectrom., 2015, 30, 1057-1063.

7. S. R. Aceto, Y. Lu, R. Narayanan, D. Heskett, E. K. Wujcik and A. Bose, Adv. Compos. Hybrid Mater., 2018, 1, 389-396.

8. A. Sharma, A. Sharma and R. K. Arya, Sep Sci Technol., 2014, 50, $1310-1320$.

9. National Primary Drinking Water Regulations, United States Environmental Protection Agency. https://www.epa.gov/ground-water-and-drinkingwater/national-primary-drinkingwater-regulations. Accessed 17 May 2017.

10. J. Zhu, S. Wei, H. Gu, S. B. Rapole, Q. Wang, Z. Luo, N. Haldolaarachchige, D. P. Young and Z. Guo, Environ. Sci. Technol., 2012, 46, 977-985.

11. M. Imamoglu and O. Tekir, Desalination, 2008, 228, 108-113.

12. S. Rengaraj, C. K. JooK, Y. Kim and J. Yi, J. Hazard Mater, 2003, 102, 257-275.

13. A. Dabrowski, Z. Hubicki, P. Podkoscielny and E. Robens, Chemosphere, 2004, 56, 91-106.

14. Z. Modrzejewska and W. Kaminski, Ind. Eng. Chem. Res., 1999, 38, 4946-4950.

15. H. A. Qdais and H. Moussa, Desalination, 2004, 164, 105-110.

16. N. Kongsricharoern and C. Polprasert, Water Sci. Technol., 1996, 34, 109-116

17. M. Hunsom, K. Pruksathorn, S. Damronglerd, H. Vergnes and P. Duverneuil, Water Res., 2005, 39, 610-616.

18. E. Dialynas and E. Diamadopoulos, Desalination, 2009, 238, 302-311.

19. M. Mohsen-Nia, P. Montazeri and H. Modarress, Desalination, 2007, 217, 276-281.

20. F. Fu and Q. Wang, J. Environ. Manag., 2011, 92, 407-418.

21. A. R. Karbassi and G. O. Ayaz, Int. J. Environ. Res., 2007, 1, 66-73.

22. R. Kumar, J. Chawla and I. Kaur, J. Water Health, 2015, 13, 18-33.

23. G. Ghasemzadeh, M. Momenpour, F. Omidi, M. R. Hosseini, M. Ahani and A. Barzegari, Front. Environ. Sci. Eng., 2014, 8, 471-482.

24. Y. Wu, X. Ma, M. Feng and M. Liu, J. Hazard Mater, 2008, 159, 380-384.

25. R. Sitko, E. Turek, B. Zawisza, E. Malicka, E. Talik, J. Heimann, A. Gagor, B. Feist and R. Wrzalik, Dalton Trans., 2013, 42, 5682-5689.

26. M. Hua, S. Zhang, B. Pan, W. Zhang, L. Lv and Q. Zhang, J. Hazard
Mater, 2012, 211-212, 317-331.

27. G. Zhang, J. Qu, H. Liu, R. Liu and G. Li, Environ. Sci. Technol., 2007, 41, 4613-4619.

28. O. Abollino, M. Aceto, M. Malandrino, C. Sarzanini and E. Mentasti, Water Res., 2003, 37, 1619-1627.

29. D. M. Manohar, K. A. Krishnan and T. S. Anirudhan, Water Res., 2002, 36, 1609-1619

30. L. C. Oliveira, D. I. Petkowicz, A. Smaniotto and S. B. Pergher, Water Res., 2004, 38, 3699-3704.

31. E. Erdem, N. Karapinar and R. Donat, J. Colloid Interface Sci., 2004, 280 , 309-314.

32. L. C. Hsu, S. L. Wang, Y. C. Lin, M. K. Wang, P. N. Chiang, J. C. Liu, W. H. Kuan, C. C. Chen and Y. M. Tzou, Environ. Sci. Technol., 2010, 44, 6202-6208.

33. M. X. Loukidou, K. A. Matis, A. I. Zouboulis and M. LiakopoulouKyriakidou, Water Res., 2003, 37, 4544-4552.

34. H. Gu, S. B. Rapole, J. Sharma, Y. Huang, D. Cao, H. A. Colorado, Z. Luo, N. Haldolaarachchige, D. P. Young, B. Walters, S. Wei and Z. Guo, RSC Adv., 2012, 2, 11007-11018

35. B. Qiu, C. Xu, D. Sun, H. Yi, J. Guo, X. Zhang, H. Qu, M. Guerrero, X. Wang, N. Noel, Z. Luo, Z. Guo and S. Wei, ACS Sustain. Chem. Eng., 2014, 2, 2070-2080.

36. B. Qiu, Y. Wang, D. Sun, Q. Wang, X. Zhang, B. L. Weeks, R. O'Connor, X. Huang, S. Wei and Z. Guo, J. Mater. Chem. A, 2015, 3, 9817-9825.

37. J. Gu, X. Yang, C. Li and K. Kou, Ind. Eng. Chem. Res., 2016, 55, $10941-10946$

38. A. Qian, P. Liao, S. Yuan and M. Luo, Water Res., 2014, 48, 326-334.

39. S. P. Dubey and K. Gopal, J. Hazard. Mater., 2007, 145, 465-470.

40. J. Kotaś and Z. Stasicka, Environ. Pollut., 2000, 107, 263-283.

41. M. S. Sivakami, T. Gomathi, J. Venkatesan, H. S. Jeong, S. K. Kim and P. N. Sudha, Int. J. Biol. Macromol., 2013, 57, 204-212.

42. J. Zhou, Y. Wang, J. Wang, W. Qiao, D. Long and L. Ling, J. Colloid Interface Sci., 2016, 462, 200-207.

43. W. Liu, J. Ni and X. Yin, Synergy of photocatalysis and adsorption for simultaneous removal of $\mathrm{Cr}(\mathrm{VI})$ and $\mathrm{Cr}(\mathrm{III})$ with $\mathrm{TiO}_{2}$ and titanate nanotubes. Water Res., 2014, 53, 12-25.

44. S. T. Farrell and C. B. Breslin, Environ. Sci. Technol., 2004, 38, 4671-4676

45. H. Gu, S. B. Rapole, Y. Huang, D. Cao, Z. Luo, S. Wei and Z. Guo, J. Mater. Chem. A, 2013, 1, 2011-2021.

46. L. Alidokht, A. Khataee, A. Reyhanitabar and S. Oustan, Desalination, 2011, 270, 105-110

47. B. Qiu, J. Guo, X. Zhang, D. Sun, H. Gu, Q. Wang, H. Wang, X. Wang, X. Zhang, B. L. Weeks, Z. Guo and S. Wei, ACS Appl. Mater. Interfaces, 2014, 6, 19816-19824.

48. Y. Wu, J. Zhang, Y. Tong and X. Xu, J. Hazard. Mater, 2009, 172, 1640-1645.

49. N. Melitas, O. Chuffe-Moscoso and J. Farrell, Environ. Sci. Technol., 2001, 35, 3948-3953.

50. N. Wu, H. Wei and L. Zhang, Environ. Sci. Technol., 2012, 46, 419-425.

51. S. J. Park and Y. S. Jang, J. Colloid Interface Sci., 2002, 249, 458-463.

52. D. Mohan and C. U. Pittman Jr, J. Hazard. Mater., 2006, 137, 762-811.

53. D. Sud, G. Mahajan and M. Kaur, Bioresour. Technol., 2008, 99, 6017-6027.

54. B. Gao, J. Lu, R. Zhuang and G. Zhang, J. Appl. Polym. Sci., 2009, 114, 3487-3494.

55. L. Zhang and M. Fang, Nano Today, 2010, 5, 128-142.

56. P. N. Dave and L. V. Chopda, J. Nanotechnol., 2014, 2014, 398561.

57. T. Scott, I. Popescu, R. Crane and C. Noubactep, J. Hazard. Mater, 2011, 186, 280-287.

58. R. Crane and T. Scott, J. Hazard. Mater, 2012, 211, 112-125.

59. Z. Ai, Y. Cheng, L. Zhang and J. Qiu, Environ. Sci. Technol., 2008, 42, 6955-6960.

60. L. C. A. Oliveira, R. V. R. A. Rios, J. D. Fabris, V. Garg, K. Sapag and R. M. Lago, Carbon, 2002, 40, 2177-2183.

61. S. Wei, Q. Wang, J. Zhu, L. Sun, H. Lin and Z. Guo, Nanoscale, 2011, 3, $4474-4502$

62. C. Xu, B. Qiu, H. Gu, X. Yang, H. Wei, X. Huang, Y. Wang, D. Rutman, D. Cao, S. Bhana, Z. Guo and Suying Wei, ECS J. Solid State Sci. Technol., 2014, 3, M1-M9

63. Z. Liu, L. Chen, L. Zhang, S. Poyraz, Z. Guo, X. Zhang and J. Zhu, Chem. Commun., 2014, 50, 8036-8039.

64. L. S. Zhong, J. S. Hu, H. P. Liang, A. M. Cao, W. G. Song and L. J. Wan, 
Adv. Mater, 2006, 18, 2426-2431.

65. Y. Li, B. Gao, T. Wu, D. Sun, X. Li, B. Wang and F. Lu, Water Res., 2009, 43, 3067-3075.

66. Y. Cao, J. Huang, Y. Li, S. Qiu, J. Liu, A. Khasanov, M. A. Khan, D. P. Young, F. Peng, D. Cao, X. Peng, K. Hong and Z. Guo, Carbon, 2016, 109, 640-649.

67. Y. Cao, J. Huang, X. Peng, D. Cao, A. Galaska, S. Qiu, J. Liu, M. A. Khan, D. P. Young, J. E. Ryu, H. Feng, N. Yerra and Zhanhu Guo, Carbon, 2017, $115,503-514$.

68. J. Huang, Y. Li, Y. Cao, F. Peng, Y. Cao, Q. Shao, H. Liu and Z. Guo, J. Mater. Chem. A, 2018, 6, 13062-13074.

69. H. Gu, D. Ding, P. Sameer, J. Guo, N. Yerra, Y. Huang, Z. Luo, T. C. Ho, N. Haldolaarachchige and D. P. Young, ECS Solid State Lett., 2013, 2, M65-M68.

70. X. Zhu, Y. Liu, G. Luo, F. Qian, S. Zhang and J. Chen, Environ. Sci. Technol., 2014, 48, 5840-5848.

71. J. D. Xiao, L. G. Qiu, X. Jiang, Y. J. Zhu, S. Ye and X. Jiang, Carbon, 2013, $\mathbf{5 9}, 372-382$.

72. Y. Li, S. Zhu, Q. Liu, Z. Chen, J. Gu, C. Zhu, T. Lu, D. Zhang and J. Ma, Water Res., 2013, 47, 4188-4197.

73. B. Qiu, H. Gu, X. Yan, J. Guo, Y. Wang, D. Sun, Q. Wang, M. Khan, X. Zhang, B. L. Weeks, D. P. Young, Z. Guo and S. Wei, J. Mater. Chem. A, 2014, 2, 17454-17462.

74. B. Qiu, Y. Wang, D. Sun, Q. Wang, X. Zhang, B. L. Weeks, R. O'Connor, X. Huang, S. Wei and Z. Guo, J. Mater. Chem. A, 2015, 3, 9817-9825.

75. K. Gong, Q. Hu, L. Yao, M. Li, D. Sun, Q. Shao, B. Qiu and Zhanhu Guo, ACS Sustainable Chem. Eng., 2018, 6, 7283-7291.

76. H. Gu, X. Xu, H. Zhang, C. Liang, H. Lou, C. Ma, Y. Li, Z. Guo and J. Gu, Eng. Sci., 2018, 1, 46-54.

77. H. Gu, H. Zhang, C. Ma, S. Lyu, F. Yao, C. Liang, X. Yang, J. Guo, Z. Guo and J. Gu, J. Phys. Chem. C., 2017, 121, 13265-13273.

78. H. Gu, H. Lou, D. Ling, B. Xiang and Z. Guo, RSC $A d v$., 2016, 6, $110134-$ 110145 .
79. D. Zhang, S. Wei, C. Kaila, X. Su, J. Wu, A. B. Karki, D. P. Youngd and Z Guo, Nanoscale, 2010, 2, 917-919.

80. N. Tang, W. Chen, W. Zhong, H. Y. Jiang, S. L. Huang and Y. W. Du, Carbon, 2006, 44, 423-427.

81. S. H. Park, S. M. Jo, D. Y. Kim, W. S. Lee and B. C. Kim, Synth. Met., 2005, 150, 265-270.

82. J. Huang, Y. Cao, Q. Shao, X. Peng and Zhanhu Guo, Ind. Eng. Chem. Res., 2017, 56, $10689-10701$.

83. L. Chen, T. Ji, L. Mu, Y. Shi, L. Brisbin, Z. Guo, M. A. Khan, D. P. Young and J. Zhu, RSC Adv., 2016, 6, 2259-2269.

84. J. Zhu, H. Gu, J. Guo, M. Chen, H. Wei, Z. Luo, H. A. Colorado, N. Yerra, D. Ding, T. C. Ho, N. Haldolaarachchige, J. Hopper, D. P. Young, Z. Guo and S. Wei, J. Mater. Chem. A, 2014, 2, 2256-2265.

85. B. Qiu, C. Xu, D. Sun, Q. Wang, H. Gu, X. Zhang, B. L. Weeks, J. Hopper, T. C. Ho, Z. Guo and S. Wei, Appl. Surface Sci., 2015, 334, 7-14.

86. K. Gong, Q. Hu, Y. Xiao, X. Cheng, H. Liu, N. Wang, B. Qiu and Z. Guo, J. Mater. Chem. A, 2018, 6, 11119-11128.

87. Q. Hu, C. Guo, D. Sun, Y. Ma, B. Qiu and Z. Guo, ACS Sustainable Chem. Eng., 2017, 5, 11788-11796.

88. K. Gong, S. Guo, Y. Zhao, Q. Hu, H. Liu, D. Sun, M. Li, B. Qiu and Z. Guo, J. Mater. Chem. A, 2018, 6, 16824-16832.

89. B. Qiu, C. Xu, Dd Sun, H. Wei, X. Zhang, J. Guo, Q. Wang, D. Rutman, Z. Guo and S. Wei, RSC Adv., 2014, 4, 29855-29865.

90. F. Gao, H. Gu, H. Wang, X. Wang, B. Xiang and Z. Guo, RSC Adv., 2015, 5, 60208-60219.

91. Y. Ma, L. Lv, Y. Guo, Y. Fu, Q. Shao, T. Wu, S. Guo, K. Sun, X. Guo, E. K. Wujcik and Z. Guo, Polymer, 2017, 128, 12-23.

92. B. Wang, Y. Wang, P. Zhou, Z. Liu, S. Luo, W. Chu and Z. Guo, Colloid. Surface. A., 2017, 514, 168-177.

93. Y. Wang, P. Zhou, S. Luo, S. Guo, J. Lin, Q. Shao, X, Guo, Z. Liu, J. Shen, B. Wang and Z. Guo, Adv. Polym. Technol., in press, doi: 10.1002/adv.21969.

94. Y. Wang, P. Zhou, S. Luo, X. Liao, B. Wang, Q. Shao, X. Guo and Zhanhu Guo, Langmuir, 2018, 34, 7859-7868. 